\title{
Effectiveness of siwak salvadora persica extract to aggregatibacter actinomycetemcomitans as one of pathogenic bacteria causing periodontal disease
}

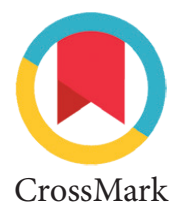

\author{
Arni I. Djais, Vidya Y. Tope*
}

\section{Abstract}

Objective: Periodontal disease is one of oral and dental diseases which most commonly found in humans caused by several factors, one of them due to the accumulation of bacterial plaque. Aggregatibacter actinomycetemcomitans is a bacterial pathogen that frequently causes periodontal disease.

Material and Methods: Sample of A. actinomycetemcomitans colonies in MHA medium. Twenty four samples were divided into six treatment groups, they were 5 groups given the extract siwak with concentration of $3.125 \%, 6: 25 \%, 12.5 \%$, $25 \%, 50 \%$ and 1 group treated with control DMSO 5\%. Inhibition zone was measured after 48 hours incubation at $37^{\circ} \mathrm{C}$ and measured using caliper. To inhibit the growth of these bacteria can be done by using natural ingredients that contain anti-bacterial agent.

Results: Data analysis was performed using Kruskal Wallis test. The mean diameter of inhibition zone at concentrations of $3.125 \%, 6: 25 \%$, $12.5 \%, 25 \%$ and $50 \%$ were $6.4 \mathrm{~mm}, 7.0 \mathrm{~mm}, 7.2 \mathrm{~mm}, 7.9 \mathrm{~mm}$ and $8.6 \mathrm{~mm}$.

Conclusion: Siwak extract can inhibit the growth of $A$. actinomycetemcomitans which is one of pathogenic bacteria causing periodontal disease.
Department of Periodontic, Faculty of Dentistry, Hasanuddin University, Makassar, Indonesia
*Correspondence to: Vidya Y. Tope, Department of Periodontic, Faculty of Dentistry, Hasanuddin University, Makassar, Indonesia vidyatope09@gmail.com

Received: 30 August 2016 Revised: 05 September 2016 Accepted: 01 January 2017 Available Online: 01 April 2017

Keywords: Siwak extract, Aggregatibacter actinomycetem comitans, Periodontal disease

Cite this Article: Djai Al, Tope VY. 2017. Effectiveness of siwak Salvadora Persica extract to Aggregatibacter Actinomycetemcomitans as one of pathogenic bacteria causing periodontal disease. Journal of Dentomaxillofacial Science 2(1): 28-31. D0I:10.15562/jdmfs.v2i1.449

\section{Introduction}

Periodonsium is tooth-supportive tissue which consist of gingiva, periodontal ligament, cementum and alveolar bone. It is divided into two parts i.e. gingiva that has main function in protecting the underlying tissue and connective part which consist of periodontal ligament, cementum and alveolar bone. ${ }^{1}$ According to Basic National Health Survey in 2013, national prevalence of dental and oral problems was $25.6 \%$. Sixteen provinces had dental and oral problems above the national value, they are Aceh 30.5\%, DKI Jakarta 29.1\%, Jawa Barat 28.0\%, DI Yogyakarta $32.1 \%$, Jawa Timur 28.6\%, Nusa Tenggara Barat 26.9\%, Nusa Tenggara Timur 27.2\%, Kalimantan Selatan 36.1\%, Sulawesi Utara 31.6\%, Sulawesi Tengah $35.6 \%$, Sulawesi Selatan 36.2\%, Southeast Sulawesi $28.6 \%$, Gorontalo 30.1\%, West Sulawesi 32.2\%, Maluku 27.2\% and Maluku Utara 26.9\%. ${ }^{2}$

Damage to the periodontal tissues is usually due to the accumulation of bacterial plaque on the tooth crown which then extends into the gingival sulcus and impair the adjacent gingiva. ${ }^{3}$ Most common bacteria which found in people suffering periodontal disease are porphyromonas gingivalis, treponema denticola, tannerella forsythia and A. actinomycetemcomitans. ${ }^{1}$

A. actinomycetemcomitans is one of the bacteria found in periodontal disease, including a group of gram-negative bacteria, facul-tative anaerobes, coccobacillus, non-motile, color-less and capnophilic. ${ }^{4,5}$ To inhibit the growth of these bacteria can be done in various ways, one of them is using natural ingredients from plants that contain antibacterial agents such as siwak. ${ }^{3}$

Siwak or salvadora persica is a medical plant whose roots have been widely used by many people in Africa, South America, Middle East and Asia. Siwak is a plant that is very popular in the Middle East. The World Health Organization (WHO) recommends and advocate siwak as an effective tool for oral hygiene, with softwood fiber mechanical action and its chemical therapeutic action. ${ }^{6}$ Siwak contains essential oils and a variety of other chemical compounds, i.e. Anorganic compound, such triethylamine, alkaloids, flavonoids, anthraquinone, tannins, saponins, sterols, vitamin C and inorganic compounds, such chloride, calcium, a large amount of fluoride, silica and sulfur, the chemical components of essential oils contained in miswak leaves such benzyl nitrile, eugenol, thymol, isothymol, eucalyptol, isoterpinolen and beta-caryophyllen. $^{7}$

The research results of inhibition test of siwak on porphyromonas gingivalis showed that siwak wood have inhibitory activity against porphyromonas 
gingivalis. Therefore, the authors are interested in investigating the effectiveness of siwak against A. actinomycetemcomitans which is one of the pathogenic bacteria causing periodontal disease.

\section{Material and Methods}

This was laboratory experiments research conducted at the Phytochemistry Laboratory Faculty of Pharmacy, Hasanuddin University and Microbiology Laboratory Faculty of Medicine, Hasanuddin University. Siwak wood mashed then diluted with $96 \%$ ethanol for five days. Then filtered using filter paper and the filtrate was evaporated using a rotary evaporator in order to obtain a thick extract.

Siwak extract was made into five different concentration which were $3.125 \%, 6.25 \%, 12.5 \%$, $25 \%$ and $50 \%$ with DMSO $5 \%$ as negative control.

\section{Table 1 Differences of wide of inhibition zone ( $\mathrm{mm}$ ) using siwak extract with $3.125 \%, 6.25 \%, 12.5 \%, 25 \%, 50 \%$ concentration and DMSO $5 \%$ as control}

\begin{tabular}{lccc}
\hline & & Wide of inhibition zone & \\
\cline { 3 - 3 } Intervention & $\mathbf{n}$ & Mean \pm SD & p-value \\
\hline DMSO 5\% & 4 & $6.2 \pm 0.000$ & \\
$3.125 \%$ & 4 & $6.4 \pm 0.440$ & \\
$6.25 \%$ & 4 & $7.0 \pm 0.910$ & 0.005 \\
$12.5 \%$ & 4 & $7.2 \pm 0.590$ & \\
$25 \%$ & 4 & $7.9 \pm 0.518$ & \\
$50 \%$ & 4 & $8.6 \pm 0.434$ & \\
Total & 24 & $7.2 \pm 0.990$ &
\end{tabular}

"Kruskal Wallis Test: $\mathrm{p}<0.05$; significant

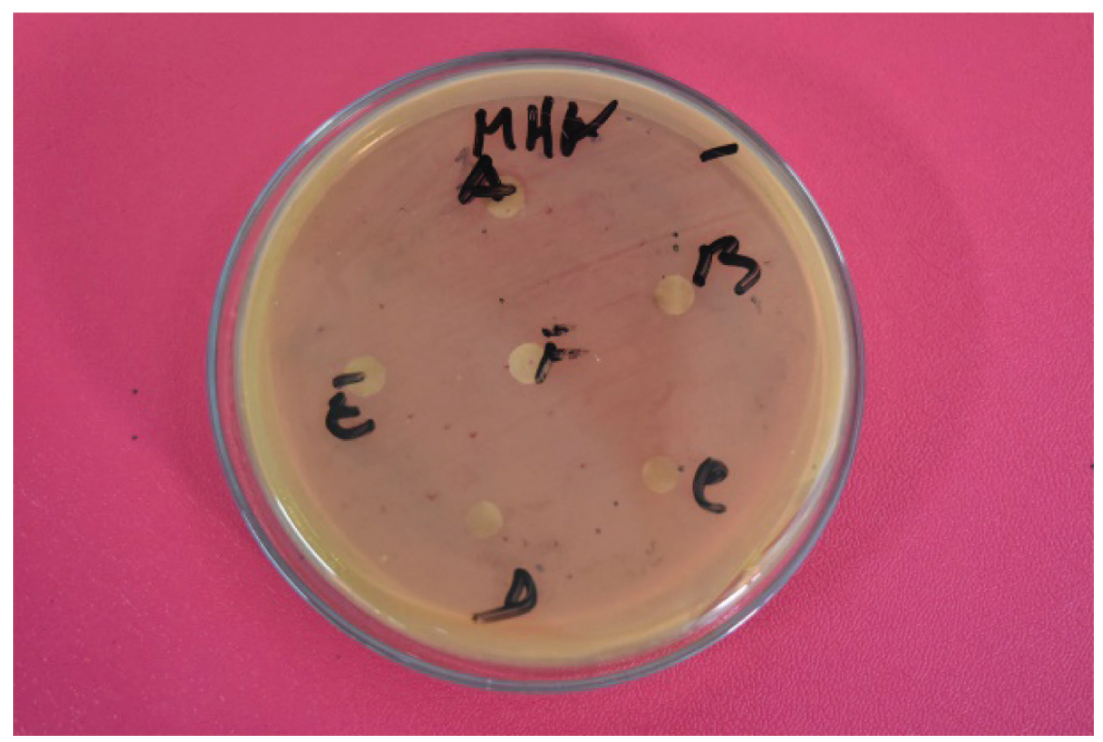

Figure 1 Inhibition zone of siwak extract on A. actinomycetemcomitans
Then, it was tested on A. actinomycetemcomitans, replication was performed four times according federer sample size formula. Incubation during $1 \times 48$ hour in temperature of $37^{\circ} \mathrm{C}$. After that, measure the clear zone using caliper.

\section{Results}

It has been performed research about the effectiveness of siwak extracts against A. actinomycetem-comitans. This laboratory experiment was conducted at the phytochemistry Laboratory, Faculty of Pharmacy and Microbiology Laboratory, Faculty of Medicine, Hasanuddin University. This posttest was only with control group design conducted in November to December 2016. This research sample is A. actinomycetemcomitans preparations that had been cultured in the laboratory.

This study used five siwak extract concentration, the concentration of $3.125 \%, 6.25 \%, 12.5 \%, 25 \%$ and $50 \%$, using $5 \%$ DMSO as a negative control. Based on the sample size formula Federer, the number of samples in each group concentration and control, respectively four samples for each group, so that the overall amount of the sample of 24 bacteria preparation. Inhibition was measured after treatment given figure 1 . The size of the clear zone that occurred was a measure of inhibition power of treatment and measured using a caliper and expressed in millimeters ( $\mathrm{mm})$. After that, data was collected, processed and analyzed using SPSS version 22.0. Results of the study appear in the table of distribution as follows:

Table 1 shows that the differences in vast of inhibition zone in each treatment and control groups, where there are four samples of bacterial preparations for each group. Based on these data, the lowest mean of board inhibition zones was at 3.125\% concentrations and the highest mean of inhibition zone was at $50 \%$ concentration. In this study, using Kruskal Wallis test it showed that p-value: 0.005 $(\mathrm{p}<0.05)$, this means that there were significant differences in vast of inhibition zones between siwak with $3.124 \%, 6: 25 \%, 12.5 \%, 25 \%, 50 \%$ concentration and control DMSO 5\% in inhibiting the growth of bacteria A. actinomycetemcomitans. Due to the results obtained meaning-ful, then the test continues to see the differences ofthe various concentrations.

In table 2 comparison of two groups of concentration that has $\mathrm{p}$-value $<0.05$ means that there were significant differences between the two groups of those concentrations, whereas the comparison of DMSO $5 \%$ with concentration of $3.125 \%$ (p:0.508), DMSO $5 \%$ with $6.25 \%$ (p:0.219), the concentration of $3.125 \%$ with $6.25 \%$ (p:0.386), the concentration of $3.125 \%$ 
Table 2 Differences between intervention groups

\begin{tabular}{lccc}
\hline Groups & & Mean \pm SD & p-value \\
\hline DMSO 5\% & $3.125 \%$ & $6.4 \pm 0.440$ & 0.508 \\
& $6.25 \%$ & $7.0 \pm 0.910$ & 0.219 \\
& $12.5 \%$ & $7.2 \pm 0.590$ & 0.013 \\
& $25 \%$ & $7.9 \pm 0.518$ & 0.013 \\
& $50 \%$ & $8.6 \pm 0.434$ & 0.013 \\
$3.125 \%$ & $6.25 \%$ & $7.0 \pm 0.910$ & 0.386 \\
& $12.5 \%$ & $7.2 \pm 0.590$ & 0.081 \\
& $25 \%$ & $7.9 \pm 0.518$ & 0.020 \\
$6.25 \%$ & $50 \%$ & $8.6 \pm 0.434$ & 0.020 \\
& $12.5 \%$ & $7.2 \pm 0.590$ & 0.772 \\
& $25 \%$ & $7.9 \pm 0.518$ & 0.245 \\
$2.5 \%$ & $50 \%$ & $8.6 \pm 0.434$ & 0.020 \\
& $25 \%$ & $7.9 \pm 0.518$ & 0.080 \\
& $50 \%$ & $8.6 \pm 0.434$ & 0.019 \\
& $50 \%$ & $8.6 \pm 0.434$ & 0.080 \\
\hline
\end{tabular}

"Mann Whitney test: $\mathrm{p}<0.05$; significant

with $12.5 \%$ (p:0.081), the concentration of $6.25 \%$ with $12.5 \%$ (p:0.772), the concentration of $6.25 \%$ with $25 \%$ (p:0.245), the concentration of $12.5 \%$ with $25 \%$ (p:0,080), concentration of $25 \%$ with $50 \%$ (p:0,080) has a value of $p>0.05$ so there were no significant difference between the groups.

\section{Discussion}

Periodontal disease is a dental and oral diseases which most commonly found in humans, caused by several factors, one of them due to the accumulation of bacterial plaque. A. actinomycetemcomitans is pathogenic bacteria that frequently causes periodontal disease. To inhibit the growth of these bacteria can be done by using natural ingredients that contain anti-bacterialagent. One of the natural ingredients that contain antibacterial substances is siwak.

In the study conducted by Ashshobirin et al. ${ }^{3}$ showed that siwak wood extract can inhibit the growth of bacteria porphyromonas gingivalis, this is due to the chemical compounds contained in siwak wood containing antibacterial activity such as saponins, flavonoids, tannins, alkaloids and terpenoid. ${ }^{3}$

Research by Santoso $^{8}$ that the effect of the siwak extract solution can inhibit the growth of S. mutans in vitro and in vivo. ${ }^{8}$ Al-Bayaty also expressed alcohol extract of siwak produce good and safe antibacterial activity Besides of antibacterial, Kumar et al. ${ }^{9}$ stated that siwak also contains antiulcer, antifungal, antipara-sitic and antivirus. ${ }^{9}$
Based on the researches above, this study was conducted in order to investigate whether siwak extract can inhibit the growth of bacteria A. actinomycetemcomitans, which is one of the pathogenic bacteria causing periodontal diseases.

Siwak mashed and dried and then mixed with $96 \%$ ethanol and allowed to stand for five days. Then, the results of immersion filtered using filter paper and evaporated using rotary evaporator in order to obtain thick siwak extract. Siwak extract later made into five different concentration, i.e. $3.125 \%, 6.25 \%$, $12.5 \%, 25 \%$ and $50 \%$ by using $5 \%$ DMSO as negative control, and then dropped into the paper disc and put it on preparation of A. actinomycetemcomitans. Then incubated for 48 hours and measuring inhibition zone using caliper. Large zone of inhibition continues to increase with increasing concentration of siwak extract. The highest inhibition zone presented in $50 \%$ concentrations and the lowest inhibition zone was at $3.125 \%$ concentration. The higher siwak extract concentration, the higher its antibacterial activity.

The data was tested using Kruskal Wallis to determine significance of inhibition zone on different concentration of siwak extract, test to determine the differences between the six treatment groups. The results obtained have significant difference at each concentration, except DMSO 5\% with siwak extract at $3.125 \%$ concentration, DMSO 5\% with siwak extract at $6.25 \%$ concentration, siwak extract at $3.125 \%$ concentration with $6.25 \%$, siwak extract at $3.125 \%$ compared with $12.5 \%$, concentration of $6.25 \%$ with $12.5 \%$, siwak extract at $6.25 \%$ with $25 \%$, siwak extract at $12.5 \%$ with $25 \%$, siwak extract at $25 \%$ with $50 \%$.

The results showed that the siwak extract can inhibit A. actinomycetemcomitans, with highest concentration of $50 \%$ and the lowest concentration of $3,125 \%$. The antibacterial activity because siwak has compounds that can inhibit the growth of bacteria, such as tannins, saponins, flavo-noids, alkaloids and terpenoids with a different mechanism. Tannins and flavonoids can interfere cell's permeability by wrinkled the cell walls. Disruption permeability, the cell cannot do its activities so that growth is impaired. Saponins have $\mathrm{OH}$ groups that destroy bacteria by destroying the cell wall and penetrate into the cell by dissolving the lipid layer. Alkaloids cause cell wall layers are not fully formed and cause cell death by disrupting components of the peptidoglycan in the bacteria cell. ${ }^{3}$

\section{Conclusion}

Siwak extract can inhibit the growth of A. actinomycetemcomitans which is one of 
pathogenic bacteria causing periodontal disease. The higher concentration of siwak extract, the greater its inhibitory power. The highest concentration which can inhibit the growth of A. actinomycetemcomitans is $50 \%$ concentration and the lowest concentration is $3.125 \%$.

\section{Conflict of Interest}

The authors report no conflict of interest.

\section{References}

1. Newman MG, Takei HH, Klokkevold PR, et al. Carranza’s clinical Periodontology; 2012.

2. RI KK. Riset kesehatan dasar 2013.

3. Ashshobirin A, Dhartono AP, Ramadhany CA, et al. Efektifitas antibakteri ekstrak kayu siwak (Salvadora Persica) terhadap pertumbuhan bakteri Porphyromonas Gingivalis J BIMKGI 2014;2: 12-23.

4. Jain R, Mittal K, Kapoor S. Virulence factors of A.Actinomycetemcomitans. J Pharm Biomed Sci 2013;34: 1693-1698.
5. Bjurshammar N. On the red fluorescence emission of Aggregatibacter Actinomycetemcomitans. Open Journal of Stomatology 2012;2: 299-306.

6. Al-bayaty FH, Al-koubaisi AH, Ali NAW, et al. Effect of mouth wash extracted from Salvadora Persica miswak on dental plaque formation: A clinical trail. J Med Plant Res 2010;4: 1446-1454.

7. Marusin S, Chairul. Efek ekstrak air dan alkohol pada siwak (Salvadora Persica L.) terhadap peningkatan aktivitas dan kapasitas fagositosis sel Makrofag. Media Litbang Kesehatan 2012;22: 38-44.

8. Santoso O, Wardani AP, Kusumasari N. Pengaruh larutan ekstrak siwak (Salvadora Persica) terhadap Streptococcus mutans: studi in vitro dan in vivo. M Med Indones 2012;46: 163-167.

9. Kumar S, Rani C, Mangal M. A Critical review on Salvadora Persica: An important medicinal plant of arid zone. Int J phytomedicine 2012;4: 292-303.

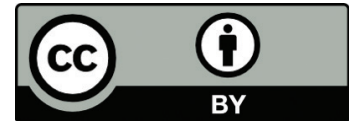

This work is licensed under a Creative Commons Attribution 